Onsekiz Mart University, kaya.filiz@yahoo.com, Çanakkale-Turkey

\title{
http://dx.doi.org/10.12739/NWSA.2013.8.3.D0139
}

\section{KEMENÇE SAZINDA USTA İCRACILIĞA YÖNELİK DAĞAR ÖNERİLERİ}

\section{ÖZET}

Bu araştırma, Türk müziğinde usta icracılık kavramına ve önemine değinerek, dört telli kemençe sazında usta icracılığa yönelik dağar önerileri sunmayı amaçlamaktadır. Araştırmanın evrenini, Türkiye'de kemençe alanında eğitim ve öğretim yapan üniversitelerin ilgili bölümleri, Türkiye Radyo Televizyon(TRT) Kurumu bünyesinde faaliyet gösteren TRT Radyoları, Kültür ve Turizm Bakanlığı'na bağlı devlet koroları ile özel kurum ve kuruluşlarda çalışan kişiler, örneklemini ise araştırmaya gönüllü olarak katılım sağlayan alanda araştırma yapmış araştırmacılar, sanatçılar ve öğretim elemanlarından oluşan onbir kişi oluşturmaktadır. Araştırmaya veri sağlamak amacıyla yapılandırılmış görüşme formu hazırlanmış ve gönüllü olarak araştırmaya katılan çalışma grubuna uygulanmıştır. Elde edilen bulgular ışığında araştırmanın problemlerine yönelik çözüm önerilerinde bulunulmuş ve dört telli kemençe sazında usta icracılığa yönelik dağar önerileri sunulmuştur.

Anahtar Kelimeler: Türk Müziği, Çalgı Eğitimi, Kemençe, Dağar, Usta İcracılık

\section{REPERTORY SUGGESTIONS CONCERNING VIRTUOSITY IN KEMANCHA}

\section{ABSTRACT}

This study aims to stress the importance of the virtuosity in Turkish music and to propose repertory suggestions concerning virtuosity in four-stringed kemancha. Research universe consists of faculties providing kemancha education in Turkey, TRT Radio, Ministry of Culture and Tourism state choirs, and people working in private organizations. Sampling of this study consists of 11 (eleven) people of various professions such as experts, researches, artists, and scholars who participated in this study voluntarily. Various interview forms have been prepared and used to provide data for the study. As a result of the acquired data several solution methods have been devised for solving the problems of the research and various suggestions concerning virtuosity in four-stringed kemancha have been offered.

Keywords: Turkish Music, Instrument Training, Kemancha, Repertory, Virtuosity. 


\section{GÍRIŞ (INTRODUCTION)}

Klasik Türk müziğinin tarihsel sürecine baktığımızda, bugün yazılı veya sözlü aktarımlarla günümüze ulaşan, sahip olduğumuz dağarın çok büyük bir kısmının sözlü eserlerden oluştuğunu görüyoruz. Bu durumda, sözlü bir müziğe sahip olduğumuzu söylemek mümkündür.

Klasik Türk saz müziği, 20 yy. itibari ile daha çok ilgi görmeye başlamış, saz müziği bestecileri çoğaldıkça, klasik Türk müziği dağarı içerisinde önemli bir noktaya gelmiştir. Tanburi Cemil Bey, Refik Fersan, Refik Tal'at Alpman, Şerif Muhittin Targan gibi önemli isimler zamanında saz müziği daha dikkat çekici bir konuma gelmiştir. Çalgının sese eşliğinin yanında, kendi ses özelliklerini gösterebileceği ve solistlik yapabileceği düşüncesi olgunlaşmış, çalgıya özel eser yazmanın önemi keşfedilmeye başlanmıştır.

Türk müziği her ne kadar sözlü bir müzik olsa da çalgı olmadan sözlü müzik icra edilemez. Saz sözün eşlikçisidir. Müzik aktarımındaki en önemli araçtır. Bu durumda mesleki çalgı eğitimi veren kurumlarda çalgı eğitiminin önemi daha da artmaktadır.

Çalgı eğitimi, çalgı çalmanın gerçekleşmesi ve çalgıyı seslendirmek için bireyin davranışlarında teknik ve estetik nitelikli yeni davranışlar geliştirmek amacıyla uygulanan süreçlerin tümüdür. Çalgı öğretim sürecinde bilgi, beceri kazanılır ve davranış geliştirilir, böylece estetik anlayış gelişir ve müziksel kişilik oluşumu sağlanır (Demirbatır, 1998:6).

Çalgl eğitimi, müzik eğitiminin önemli bir bölümüdür. Türk müziğinde de çalgı eğitimi geçmişten günümüze varlığını sürdürmüştür. Türk müziği çalgı eğitimine baktığımızda yakın bir zamana kadar ustaçırak ilişkisine (Meşk Sistemi) dayandığını görürüz.

Musikide meşk, bir üstat tarafından musiki parçasının tedricen çalınması ve okunması suretiyle talebeye öğretilmesi ve talebe tarafından öğrenilmesi demektir(Behar, 1992: 24). Türk musikisinde notanın kullanılmadığı zamanlarda oldukça önemli bir işleve sahip olan meşk, musiki üstatlarınca devam ettirilmiş ve bu suretle belirli bazı üsluplar, asırlarca sonraya taşındığı gibi musiki eserleri de haflzadan hafızaya aktarılmak suretiyle unutulmaktan kurtarılmıştır(Gerçek, 2008:2). Tüm bu olumlu yanlarının yanında meşk kulaktan kulağa yapılan bir eğitim sistemi olduğu için çalgı metotlarına ihtiyaç duyulmamıştır.

Türk müziğinin, Batı müziği nota yazısıyla tanışması XIX. yüzyıla rastlar. Yeni nota yazısının yaygınlık kazanmasıyla da çalgı metotları literatürdeki yerlerini almaya başlar. "Türk müziği tarihinde bilinen ilk matbu saz metodu, Ali Salâhi Bey'in (1878-1945) ud metodudur. Bu metot, çok anlamlı bir başlıkla, "Hocasız Ud Öğrenmek Usûlü" adı altında 1910 yılında yayınlanmıştır"(Behar, 1992:104).

Günümüzde, Türk müziği çalgı eğitimine baktığımızda, akademik çalgı eğitimi yerleşmeye başlamış, bilimsel boyutta yapılan çalışmalar ışığında çalgı eğitimi bir sistematiğe ve standarda oturtulma çabasına girmiştir. Eğitimi bilimsel temellere oturtma bilincinin gelişmesi ile metotların yazılmaya başlanması, eğitim programlarının hazırlanması, öğrenci merkezli bir düşünce yapısının oluşması çalgı eğitiminin değişen boyutlarıdır.

Akademik eğitimin önem kazandığı, müziğin bilim olarak algılanmaya başladığı son yıllarda Türk müziği çalgı eğitimi konusunda önemıi çalışmalar yapılmış ve yapılmaktadır. Mesleki çalgı eğitiminde sistemli bir metot uygulamasının yanında, çalgının ses sahasına, teknik özelliklerine ve ses tınısına uygun etüt ve dağar seçimi de büyük önem taşımaktadır.

Olumlu gelişmelerin yanında özellikle çalgı eğitimi konusunda yapılan çalışmaların yeterli sayıda olmadığı açıktır. Klasik Türk 
müziği çalgılarının eğitim sürecine baktığımızda gözümüze çarpan bazı sıkıntılar vardır. Bunlardan biri yeterli sayıda metot çalışmasının bulunmaması diğeri ise çalgı eğitimi sırasında faydalanılabilecek çalgıya özel yazılmış etüt ve eser dağarının yeterli olmayışıdır.

Bu çalışmada; çalgıya özel dağar geliştirmenin önemi üzerinde durularak, dört telli kemençe sazında usta icracılığa yönelik dağar önerileri sunulacaktır.

\section{2. ÇALIŞMANIN AMACI (RESEARCH PURPOSE)}

Bu çalışmanın amacı, usta icracılığın önemini vurgulayarak, kemençe usta icracılık eğitiminde kullanılabilecek ve usta icracıların konserleri için kaynak oluşturabilecekleri bir dağar önerisi sunmaktır. Usta icracılığı tanımlamak, sorgulamak, usta icracılığa yönelik akademik çalgı eğitiminin önemini vurgulamak ve Türk müziği çalgı eğitiminde çalgıya özel dağarın gerekliliği üzerinde durmak ise araştırmanın diğer amaçlarını ortaya koymaktadır.

\section{3. ÇALIŞMANIN ÖNEMI (RESEARCH SIGNIFICANCE)}

Çalgı müziği dağarının geliştirilmesinin gerekliliğine değinmesi, usta icracılığın önemini vurgulaması, Türk müziğinde ustalık kavramını ele alması, kemençe sazında usta icracılık için ölçütleri belirlemeye çalışması, usta icracılık eğitimi ve usta icracıların konser programları için kaynak oluşturması çalışmanın önemini vurgulamaktadır.

Böyle bir çalışmanın diğer çalgılar için de kaynak ve örnek teşkil etmesi ise farklı bir kazanım sağlamaktadır. Tüm Türk müziği çalgıları için böyle bir dağar oluşturulması, Türk müziğinde usta icracılık konumuna ve usta icracılık çalgı eğitimine önemli bir katkı sunacaktır. Bu çalışmanın çalgı müziği dağarının zenginleştirilmesi için de teşvik edici bir etkisi olacaktır.

\section{4. ÇALIŞMANIN YÖNTEMİ (METHOD OF THE STUDY)}

Kemençe sazında usta icracılığa yönelik dağar önerileri sunmayı amaçlayan bu çalışma nitel araştırma yöntemine göre desenlendirilmiştir. Araştırmaya veri sağlamak amacı ile olan görüşme tekniği kullanılmıştır.

Nitel araştırmalarda görüşme iki amaçla kullanılmaktadır. İlk olarak görüşme, veri toplamak için başat bir yöntem olabilir, ikinci olarak da gözlem, döküman analizi ya da diğer teknikler ile birlikte kullanllabilir (Bogdan ve Biklen, 1998:94). "Görüşme yoluyla deneyimler, tutumlar, düşüceler, niyetler yorumlar, zihinsel algllar ve tepkiler gibi gözlenemeyen unsurlar anlaşılmaya çalışılmaktadır" (Yıldırım ve Şimşek, 2005:23).

\subsection{Araştırma Grubu (Sampling)}

Bu araştırmanın evrenini, Türkiye'de kemençe alanında eğitim ve öğretim yapan üniversitelerin ilgili bölümleri, Türkiye Radyo Televizyon(TRT) Kurumu bünyesinde faaliyet gösteren TRT Radyoları, Kültür ve Turizm Bakanlığı'na bağlı devlet koroları ile özel kurum ve kuruluşlarda çalışan kişiler, örneklemini ise araştırmaya gönüllü olarak katılım sağlayan alanda araştırma yapmış araştırmacılar, sanatçılar ve öğretim elemanlarından oluşan on bir kişi oluşturmaktadır.

Araştırmanın çalışma grubunda bulunan katılımcıların demografik özelliklerine ilişkin bulgular aşağıda sunulmaktadır. 
Tablo 1. Çalışma grubunun demografik özelliklerine göre dağılımı (Table 1. The distribution of the sampling' demographic properties)

\begin{tabular}{|c|c|c|c|}
\hline & & $f$ & $\%$ \\
\hline \multirow[t]{2}{*}{ Cinsiyet } & Kadın & 6 & 54.54 \\
\hline & Erkek & 5 & 45.46 \\
\hline \multirow{3}{*}{$\begin{array}{l}\text { Bağlı } \\
\text { Bulunan } \\
\text { Kurum }\end{array}$} & Konservatuvarda öğretim elemanı & 4 & 36.36 \\
\hline & $\begin{array}{l}\text { Kültür Bakanlığı Korolarında ve TRT Radyo } \\
\text { Televizyonu'nda Sazende }\end{array}$ & 4 & 36.36 \\
\hline & Özel kurumlarda sazende ve eğitmen & 3 & 27.28 \\
\hline \multirow{3}{*}{$\begin{array}{l}\text { Öğrenim } \\
\text { Düzeyi }\end{array}$} & Doktora/Sanatta yeterlik & 3 & 27.27 \\
\hline & Yüksek Lisans & 3 & 27.27 \\
\hline & Lisans & 5 & 45.46 \\
\hline
\end{tabular}

\subsection{Veri Toplama Araci (Data Collection Tool)}

Araştırmaya ilişkin veri toplayabilmek amacıyla yapılandırılmış görüşme formu kullanılmıştır. Ekiz, özellikle sosyal bilim araştırmacılarının bu tekniği kullandığını belirtir (2003:62). Karasar ise görüşmeyi; "sözlü iletişim yoluyla veri toplama (soruşturma) tekniği"(1994:65) olarak tanımlar.

Yapılandırılmış görüşme formunun hazırlanma süreci; ilgili alan yazının taranması, çalışma grubuna girmeyen alanda uzman müzik eğitimcisi ve akademisyenlerle görüşmeler, bu görüşmelerden elde edilen bilgilere dayalı olarak oluşturulan madde(soru) havuzu oluşturulması, eğitim bilimleri alan uzmanları(1 kişi) ve ölçmedeğerlendirme(l kişi) uzmanlarının görüş ve önerileri doğrultusunda 11 maddenin 8 maddeye indirilmesi, görüşme formuna son halinin verilmesi şeklinde özetlenebilir.

Kemençe icracılığı ve kemençe eğitimi üzerine çalışmalarda bulunan 30 uzman ismin bulunduğu listeye uzmanların da görüşleri doğrultusunda iki yeni isim daha eklenerek konu ile ilgili toplam 32 isim belirlenmiştir.

Listedeki 32 katılımcı adaydan ulaşılabilen 24 katılımcının 17 kişisi bu çalışmaya görüş ve düşünceleri ile destek vermek istediklerini ifade etmişlerdir. Ancak araştırma sürecinde tarafların yaşadığı bazı özel durumlar (hastalık, yurt içi ya da dışı geziler vb.) nedeniyle toplam 17 olan uzman kişilerden 11'i ile görüşme gerçekleştirilebilmiştir. Katılımcllarla görüşmeler 08.02.2012 ile 27.05.2012 tarihleri arasında telefon ve internet aracılığı ile gerçekleştirilmiştir. Tüm katılımcıların araştırmacıyı içten karşılaması, araştırılan konuya ilişkin motive edici tutumları araştırmacıyı cesaretlendirmiştir.

Araştırmada elde edilen veriler nitel analiz yöntemleri ile değerlendirilmiş ve sonuçlar yine nitel olarak sunulmuştur. Elde edilen sonuçların yorumlanmasında alan yazındaki ilgili araştırma sonuçları ve görüşler dikkate alınmıştır.

\subsection{Verilerin Analizi (Data Analysis)}

$\mathrm{Bu}$ çalışmada ihtiyaç analizine yönelik verilerin çözümlenmesinde, sorulara verilen cevaplar, kullanma sıklığına göre benzer cümleler arasından ilgili örnek cümlelerle, kategorilere ayrılarak maddeleştirilmiştir. Çalışma verilerinin analizinde katılımcıların görüşleri betimlenerek içerik analizi yöntemi kullanılmıştır.

\section{BULGULAR VE YORUM (FINDINGS AND COMMENTARY)}

Bu bölümde, alt problemlerin sıralanmasına uygun olarak usta icracılık kavramını tanımlamada, usta icracının ölçütlerini 
belirlemede ve dört telli kemençe eğitiminde usta icracılık için dağar belirleme aşamalarında, bu sazı icra eden değerli kemençevilerin görüşlerine ve önerilerine yer verilmiştir.

\subsection{Usta İcracı Kimdir? (Who is the Master Performer?)}

Usta icracıyı tanımlamak için katılımcılara "Sizce usta icracı kimdir?" sorusu sorulmuş alınan dönütler sonucunda şu verilere ulaşılmıştır.

Usta icracı; sazında doğru tutuş, seslendirme ve iyi ton çıkarabilme konularında hakim olabilen, sağ ve sol el hakimiyetini en üst seviyeye taşımış, her ton ve makam seslerini net ve temiz bir şekilde icra edebilen, transpozisyon konusunda kendini yetiştirmiş, müzikal yaratıcılığa sahip, soliste eşlik konusunda başarılı, solo performansta hem teknik hem de artistik yönde kendini kanıtlamış, müzik genel kültürünün yanında entelektüel bir bakış açısına sahip olan, yeniliklere açık, dünya müzik ve müzisyenlerinin takipçisi, icrasında kendine ait bir tavra (üsluba) sahip, farklı tarzlarda müzikleri icra edebilen, doğaçlama müzikal gezintileri layıkıyla yapabilen kişidir.

Görüşme formu sonucunda alınan dönütlere baktığımızda usta icracılık ünvanının önemini ve getirdiği sorumlulukları ayrıntıları ile görmekteyiz. Usta icracının sadece solo icrada değil soliste eşlik konusunda da üst seviyede olması gerekliliği bizlere Türk müziğindeki usta icracılık konumu hakkında fikir vermektedir. Yine Türk müziğinin vazgeçilmez özelliklerinden biri olan taksim formunun icracılıkta taşıdığı önem, usta icracıyı açıklayan ölçütlerin arasında dikkati çeken en önemlilerinden biri olarak karşımıza çıkmaktadır

\subsection{Virtüöz ve Usta İcracı Kavramları Birbirini Karşılar mı? (Virtuoso and Master Performer Concepts are the Same Thing?)}

Literatürde virtüöz kelimesi İtalyanca (virtuoso, Latince: virtuosus): "kabiliyetli, becerikli" anlamina gelen bir kelimedir. Genellikle müzik ve resim alanında kullanılır. Zannedildiği gibi sadece müzikte kullanılmaz. Resmi bir ünvan değil bir iltifattır. Ancak günümüzde bir ünvan gibi kullanılmaya başlanmıştır (http://tr.vikipedia.org, 2012).

Virtüöz, harcadığı çabayı dinleyiciye fark ettirmeden en büyük teknik güçlüklerin üstesinden gelebilen icracı, bir sanatta, bir etkinlikte çok yetenekli olan, büyük ustalık kazanmış kimse (resim virtüözü) anlamlarını taşımaktadır(Büyük Larousse,1986:12222). Sanat alanının bir dalında işini (teknik, tavır ve yorum bakımından) en üst seviyede yapan kişiye virtüöz, sanat alanındaki büyük ustalık becerisine ise virtüözite diyebiliriz. Kelimeye Türkçe bir karşılık verdiğimizde ise karşımıza usta kelimesi çıkmaktadır. Sanılanın aksine virtüöz kelimesi sadece müzikte değil sanatın diğer alanlarında da kullanılmaktadır.

Katılımcılara "Sizce uluslararası ölçütleri ile virtüöz kavramı, klasik Türk müziğindeki ölçütleri ile usta icracı kavramı ile uyuşmakta mıdır?" sorusu yöneltilmiş alınan dönütler doğrultusunda şu verilere ulaşılmıştır.

Kişilere "usta icracı" ve "virtüöz" kavramlarına ilişkin sorulan sorudan aldığımız yanıtlara göre; iki kelimenin aynı anlama geldiği, birinin uluslararası alanda diğerinin ise Türk müziğinde çalgısında en üst düzeyde müzikal seslendirme yapan kişi olduğu sonucuna varılmaktadır. Aldığımız cevaplara göre virtüöz ve usta icracı kavramları anlam bakımından farklılık taşımamakta olup müziğin türüne çalgıya ve coğrafyaya göre ölçütleri şekillenmekte ve iyi icracılık anlamına gelen bu kelimeler buna göre değerlendirilmektedir. 


\begin{abstract}
Alınan cevaplarda dikkati çeken bir hususu şöyle açıklayabiliriz; Klasik Batı müziği, çalgısal bir müzik yapısına sahip olmasından dolayı çalgıya özel dağarlara sahiptir. Bu virtüözitenin batı müziğinde göze çarpan bir ünvan olmasını sağlar. Bunun yanında Türk müziğinin söze dayalı bir müzik olması, bu sebeple saz eseri dağarının yeterli sayıda olmayışı usta icracı ünvanının çok fazla göze çarpmamasını açıklar. Türk müziğinde çalgıya özel yeterli dağar olmaması, dile getirilmesi ve üzerinde durulması gereken önemli bir konudur.

Bir kemençevi soruya farklı yaklaşmış ve bu iki kelimenin birbirini karşılamadığını düşündüğünü ifade ederek, usta icracılığı Türk müziği ile ilişkilendirmiş, taksim yapma yetisine sahip olan usta icracıların Batı müziğindeki virtüözlerden üstün olduğunu belirtmiştir. Sonuç olarak yine her alanda ve coğrafyada farklı şekillenen usta icracı/virtüözite ölçütleri göze çarpmaktadır.
\end{abstract}

\title{
5.3. Virtüözite ve Usta İcracılık Arasındaki Benzerlik ve Farklılıklar Nelerdir? (What are the Similarities and Differences Between Virtuosity and Master Performance?)
}

İkinci alt problem bağlamında katılımcılara "Sizce yukarıdaki soru çerçevesinde klasik Türk müziğinde kullanılan usta icracılık ve uluslararası müzik dilinde kullanılan virtüözite kavramları arasındaki benzerlik ve farklılıklar nelerdir?" Sorusu yöneltilmiş, alınan cevaplar doğrultusunda şu verilere ulaşılmıştır.

Türk müziğinde usta icracının ölçütlerini belirledikten sonra uluslararası alandaki ifadesi ile virtüözite ve bizdeki ifadesi ile usta icracı arasında oluşan, müziğin ve çalgıların farklılıklarından kaynaklanan benzerlik ve farklılıklarına göz atmak gerekir.

Görüşme formundan aldığımız sonuçlara göre virtüözite ve usta icracılık kavramlarının benzerlik ve farklılıklarını şu şekilde sıralayabiliriz;

- Klasik Batı müziğinde her enstrümanda virtüöziteyi tanımlayan veya bu eserler çalındığında evet gerçekten bu çalan kişi virtüözdür denilecek çalgıya özel eserler mevcuttur. Klasik Türk müziğinde ise birkaç besteci hariç (Şerif Muhittin Targan, Hasan Ferit Alnar, Reşat Aysu gibi) çalgıya özel bir eser repertuvarı mevcut değildir. Saz eserlerine gereken önemin verilmediği söylenebilir ki bu da klasik Türk müziğinin söze dayalı bir müzik olmasından kaynaklanmaktadır. Dolayısıyla bizdeki usta icracı kavramı daha çok sesleri temiz tınlatma ve makamlara göre perdelere hakim olmaktan öteye gidememektir.

- Virtüözite kavramının milleti, milliyeti olduğu söylenemez, iyi bir icracı dünyanın her yerinde kabul görüp ve yine dünyanın her yerinde aranan istenilen, farklı alanlardan farklı müzisyenlerle birlikte müzik yapan icracıdır. Virtüöz de usta icracı da her müzikte her ortamda aynıdır, sadece bu kriterler her müziğe göre farklılık gösterir. Örneğin; Hindistan'daki bir tabla icracısı ile Koreli bir gayageum icracısı tabî̀ ki farklı kriterler çerçevesinde değerlendirilecektir.

- Türk Müziği söz müziği ağırlıklı bir müzik olup saz müziği 20 yy. itibari ile önem kazanmıştır. Klasik müziğe baktığımızda ise karşımıza neredeyse (opera, müzikal, operet vs. eserleri hariç) hiç sözlü eser çıkmamaktadır. Bu durumda çalgı müziği ve çalgılar önem kazanmış, çalgılara özel eserler ve etütler yazılmıştır. Dolayısı ile uluslararası benimsenmiş bir müzik olan klasik müzikteki virtüözite kavramında çalgıya özel yazılmış eserler ve bu eserlerden oluşan her saz için 
belirtilmiş eser ve teknik kriterler mevcuttur. Bu durum bizim müziğimizle kıyaslanır ise bizim müziğimizdeki usta icracıların eser repertuvar ve teknik kriterleri bizim müziğimizin yapısal boyutuna göre şekillenecektir. Kavramların arasında anlam bakımından bir farklılık değil, sahip oldukları müzikal yapı, çalgılar ve çalgı repertuvarı kriterleri arasında farklılık mevcuttur.

- "Ulusallık" ve "uluslar arasılık" kavramları farklı kültürel değerlere sahip olabilmektedirler. Milli müziğimizin geleneksel tarafını yansıtan Türk müziği (Makam Müziği + Halk Müziği), her uluslararası geleneksel müzik gibi kendine özgü değerlere sahiptir. Bu değerler çerçevesinde "usta icracılık" kavramı, uluslararası platformda yer alan "virtüözite" kavramı ile aynı anlama gelse de, öğrenim sistemi, uygulama ve müzikal gelişim bakımından farklılık göstermektedir.

- Türk müziği alanındaki en büyük zorluklardan biri olarak karşımıza transpoze sorunu çıkmaktadır. Çünkü hangi eseri nereden icra edecek olursanı olun karşınızda aynı nota bulunmaktadır. Klasik Batı müziğinde ise eser hangi tonda bestelenmişse o tonda çalınmaktadır. Bizim ki gibi bir durumu onların karşısına getirdiğinizde sanırım gülümseyeceklerdir. İki kavram anlam bakımından aynı şeyi anlatsa da farklı müzikler olarak değerlendirdiğimizde bizim müziğimizdeki usta icracılar transpoze yapabilme konusunda daha fazla yeterliliğe sahiptirler.

- İki kavram anlam bakımından farklılık taşımasa da Türk müziği karakteristik ve uygulama özellikleri bakımından doğaçlamayı içinde barındıran bir müziktir. Türk müziğindeki virtüözler doğaçlama konusundaki hâkimiyetleri ile farklılık kazanmaktadırlar.

- Virtüöz de usta icracı da çalgının tüm teknik olanaklarını zorlayan bir icra geliştirmek ve iyi müzik ortaya çıkarmakla mükelleftir. Müziğin yapısı, çalgıların farklılığı ve geleneksel müzik boyutu işin içine girdiğinde öğretim yöntemleri, çalgıda yapısal gelişime bağlı standardizasyon, çalgının yan aksesuarlarının imali, müziğe hak ettiği önemi veren devlet politikası vb. gibi konularda farklılıklar ortaya çıkmaktadır.

Aldığımız cevaplar bir önceki soruya paralel şekillenmiştir. Kelimelerin anlam olarak aynı olduğu öğretim yöntemlerine, çalgıda yapısal gelişime bağlı standardizasyona, çalgının yan aksesuarlarının imaline, müziğe hak ettiği önemi veren devlet politikalarına, uygulama alanlarına, bulunduğu coğrafyaya ve müzik türüne göre değerlendirme ölçütlerinin değişeceği sonucuna varılmıştır.

Türkiye çerçevesinde konuya yaklaştığımızda sanat eğitimi politikalarına göz atmak gerekir. Bu konuyu irdelemek, şu anki konumunu getirilerini ve eksiklerini tespit ederek nasıl iyileştirileceği konusunda çözümler üretmek sanatın daha da gelişmesi adına faydalı olacaktır. Bu bağlamda usta icracı ünvanı da giderek dikkat çekmeye ve hakkettiği değeri görmeye doğru yaklaşacaktır.

\subsection{Klasik Türk Müziği Seslendiriciliğinde Çalgının Önemi Nedir? (What is the Point of Instrument at Play Turkish Classical Music?)}

Uluslararası alanda kabul görmüş klasik Batı müziği ile klasik Türk müziğinin yapısal farklılıklarından ve çalgıların farklılıklarından doğan usta icracı ölçütlerindeki değişiklikleri göz önüne aldığımızda belki de dikkatimizi en çok çeken durum çalgı müziği 
dağarının yeterli sayıda olmayışıdır. Bu durumun en gerçekçi dayanağı Türk müziğinin söze dayalı bir müzik oluşudur. Klasik Türk müziğinin, son dönem çalgı müziği adına yaşadığı gelişmeyi de göz önüne aldığımızda tahminen olo'luk bir kısmı saz müziği dağarını oluşturmaktadır. Bu tablo karşımıza başka bir soruyu çıkarmaktadır. Klasik Türk müziği seslendiriciliğinde çalgının yeri nedir? Bu soruya cevap aramak için katılımcllara "Sizce, klasik Türk müziği seslendiriciliğinde çalgının yeri; sadece söze eşlik midir yoksa çalgının tınısal ve teknik özellikleriyle etki meydana getirmek midir?" Sorusu sorulmuş alınan dönütler sonucunda şu verilere ulaşılmıştır.

- Çalgı her iki alanda da farklı önem arz eder. Sözlü bir esere eşlik ediliyorsa eşlik önceliktir ve çalgının özellikleri göz önüne alınarak eşlik edilmelidir. Fakat söz konusu saz müziği ise burada öncelikler değişir. Sazın tınısı, çıkarılan ton, teknik hâkimiyet, tavır ve kişisel yorum ön plana çıkar. Her iki icra türünde de perde hassasiyeti olmazsa olmaz bir konudur ve en üst seviyede dikkat edilmesi gerekir.

- Türk müziğinde soliste eşlikte yapılan toplu icralarda çalgılar her zaman tam anlamıyla tınısal özelliklerini gösterememektedir. Teknik özellikleri göstermek ise eşlikte ve toplu icrada mümkün değildir. Eşlik icracısı ve usta icracı kriterleri farklılık göstermekte ve müziğimizde her iki alanda da başarılı icracılar yetiştirilmektedir.

- Türk müziğinin söze dayalı bir müzik olduğunu düşündüğümüzde eşlik konusu büyük önem kazanmaktadır. Soliste eşlik gerçek anlamda zor ve ustalık gerektiren bir iştir. Çalgının tınısal ve teknik özellikleri ile etki meydana getirmek için de doğru eserler doğru ton çıkarma ve her konuda çalgıya hâkimiyet çok önemlidir. Usta icracı her iki icra vasfına da sahip olmalıdır.

- Bu konu, geleneksel ve modern olmak üzere iki alanda ele alınabilir. Geleneksel sözlü eser icraları söz konusuysa sazendenin ve hanendenin, eserin yazıldığı döneme ait üslubu yansıtması gerekmektedir. Her dönemde öne çıkan müzikal öğeler değişmekte olduğundan, eserlerin dinamik, romantik, sade, süslü vb. açılardan seslendirilmeleri farklılık yaratmaktadır. Geleneksel saz eseri icralarında da, döneme ve bestekâra uygunluk önem taşımaktadır. Çalgıların teknik özelıiklerini yansıtabilmelerine olanak sağlayan saz eserleri (sözsüz eserler) ise, son yüzyıllara ait bir özellik olarak ortaya çıkmıştır. Bu bağlamda, Türk makam müziği seslendiriciliğinde çalgının yeri, ne sadece söze eşlik, ne de çalgının tınısal ve teknik özelliklerinin ön plana çıkarılması olmalıdır. Bestecinin isteği doğrultusunda hareket edilmeli, bu bilinemiyorsa, eserlerin ait oldukları dönemin üslubu dikkate alınmalıdır.

- Türk müziğinin çok belirleyici bir özelliği vardır. Bu, Batı müziğinden farklı olarak Türk müziğinin çalgısal bir müzik olmayışı, temel çizgisinin solist esaslı bir müzik oluşudur. Dolayısıyla Türk müziğinde her zaman çalgılar ikinci planda kalmış, deyim yerindeyse çalgıların fonksiyonu hep solisti "asiste etmek" ten ibaret olmuştur. Enstrümantal olarak bestelenen müzik eserlerinde bile (Peşrev, Saz Semaisi, Longa, Sirto) bestecinin ufku ve eserlerin sınırları çalgıda sanki bir solist varmış gibi besteleme tekniğini geçememiştir. Kaldı ki Türk müziğinin elimizde bulunan eserlerinin içinde saz eserlerinin toplamının 6-7 oranını bile bulamayışı çalgısal müziğin Türk müziğindeki önemini gösterir. Türk müziği çalgıları 
için bestelenen eser sayısı maalesef yok denecek kadar azdır. Şu çok iyi bilinen bir gerçektir ki müzikte özel olarak çalgılar için yapılan beste ve çalışmalar çalgıların gelişiminin temel dinamiğidir.

Türk müziği yüzyıllardır süregelen köklü bir müziktir. Eserler insan sesine göre şekillenmiş, çalgıların müzikteki yeri de bu bağlamda oluşmuştur. Taksimler dışında solo performans sergileme düşüncesi 20. yüzyılın başlarında dikkat çekmeye başlamış, saz müziği kendine Türk müziği dağarı içerisinde önemli bir yer edinmiştir. Çalgının yeri 20. yy itibari ile sadece söze eşlikten ibaret olmaktan çıkarak, saz eserlerinin çoğalması ile sazların solo performansları da önem kazanmıştır. Tanburi Cemil Bey ile başlayan usta icracılık konumu giderek dikkat çekmeye başlamış, saz müziği besteciliğine doğru bir yöneliş gerçekleşmiştir. Tüm bunlar çerçevesinde çalgının Türk müziğindeki yeri hem soliste eşlik hem de solo icradır diyebilmek mümkündür.

\subsection{Usta İcracılığa Yönelik Akademik Eğitim (Education for Master Performer)}

Usta icracılığa yönelik akademik eğitimin önemi nedir? Sorusunu cevaplamak adına katılımcılara "Günümüzde usta icracılığa yönelik akademik eğitim gerekli midir?" sorusu sorulmuş ve alınan dönütler sonucunda şu verilere ulaşılmıştır.

- Kesinlikle gereklidir ama bu akademik eğitim nasıl olmalıdır? Şu anki müziği bağlayan akademik sistem, arzulanan sistem midir?

- Akademik bir eğitim her zaman gereklidir. Usta- çırak ilişkisi de her zaman geçerlidir. Bu çerçevede zaten akademik çalgı eğitiminde de usta-çırak ilişkisi halen devam etmektedir ve etmelidir.

- Sadece usta icracılığa yönelik akademik eğitim değil, çalgı eğitiminin her aşamasında sistemli metot eğitimi şarttır. Tabi ki usta-çırak eğitimi göz ardı edilemez ama değişen ve gelişen eğitim platformunda sistemli metot ile verilecek eğitim her aşamada daha faydalı olacaktır.

- Bir çalgı virtüözünün hem sazında hem de Türk müziği ve nazariyatında akademik eğitim alması şarttır.

- Akademik eğitim mutlaka gereklidir. İleri derecede solfej ve müzik bilgisi olmadan usta icracı olabilmek mümkün olmayacaktır. Ancak üstün yetenekli kişiler belki bu eğitimi almadan da ustalaşabilirler (İhsan Özgen örneği gibi) .

- Gelişen çağımızda akademik eğitim mutlaka gereklidir. 1800 1900'lerin virtüöz - ustalık kavramı ile bu günkü anlayış arasında büyük farklar vardır. Her gün hızlanan, gelişen bir dünya var. Bu gelişimleri ancak akademik bir eğitim ile yakalayabiliriz.

Türk müziğinin sözlü eserlerin çoğunluğunda oluşan bir müzik olmasına karşın son dönemlerde (20. yüzyılın başlarından itibaren) saz müziği önem kazanmaya başlamış, Türklere ve Türk müziğine ait çalgıların büyüsü, güzelliği ve etkileyici yanı keşfedilmiş, çalgısında kendini kanıtlamış usta icracılar ve çalgı müziği bestekârları yetişmeye başlamıştır.

Çalgı müziğinin son dönemdeki gelişimini düşündüğümüzde ise akademik çalgı eğitiminin önemi göz ardı edilemeyecek boyutlara gelmektedir. Usta icracılığa yönelik akademik eğitimin de biran önce eğitim programlarına alınması gereklidir. Böylelikle hem çalgı müziği ilerleyecek hem de usta icracılık hak ettiği değere ulaşacaktır. 


\subsection{Kemençe sazında usta icracı ölçütleri nelerdir? (What are Criterias about Master Performer at Kemancha?)}

Katılımcılara "Sizce kemençede usta icracı ölçütleri neler olmalıdır?" sorusu sorulmuş alınan dönütler sonucunda şu verilere ulaşılmıştır.

- Sazı doğru tutmak,

- Sazdan doğru ve güzel ton çıkarmak,

- Her makama ait perdeleri doğru basabilmek,

- Özellikle tiz pozisyonlardaki hâkimiyet sağlayabilmek,

- Teknik hâkimiyeti(sürat, pozisyon, yay kullanımı) sağlayabilmek,

- Eseri özünü bozmadan yorumlayabilmek,

- Transpozisyon hâkimiyetine sahip olmak,

- Dikte yeteneğinin ve hafızasının kuvvetli olması gerekir. Böylelikle ilk gördüğü eseri hemen hemen yanlışsız çalabilir.

- En önemlisi de icrasına kendinden bir şeyler katabilmeli ve tavır ve tarzı kendine özel olmalıdır. Dinlendiği zaman fark edilir bir kemençevi olabilmelidir.

- Klasik kemençede usta icracı olabilmek için hem usta-çırak ilişkisini devam ettirmek hem farklı yorumları dinlemek hem de iyi bir eğitime sahip olmak gereklidir.

- Kemençe sazında vibrasyon oldukça önemli bir yer tutmaktadır. İcracının bunu dengelemesi gerekmektedir aksi takdirde detonasyon ve sürtonasyon gerçekleşir.

- Kemençe kaç telli veya hangi boylarda olursa olsun, sazın teknik zorluklarını yenebilen, belli bir müzikal estetiğe ve üsluba sahip, çevresinde kabul görmüş her müzisyen kemençe sanatçısı "usta icracı" olarak anılabilir.

- Yayı doğru şekilde kullanmalıdır.

- Deşifrasyonu ileri olmalıdır.

- Ritim duygusu ileri seviyede olmalıdır.

- Taksim yaparken makamlar arası geçişlerde başarılı olması ve makam geçişlerinde farklı tonları kullanmakta ustalık göstermesi gerekir (Örneğin; 4 ses hicazdan, yerinde rasta geçmek gibi) .

- Farklı tonlarda çalarken, kemençe hâkimiyeti yüksek olmalıdır.

- Farkli müzik türlerini icra edebilmelidir.

- Türk müziği makamlarını iyi bilmeli, bu sayede çalınan eserlerdeki geçkileri iyi kavrayabilmelidir.

- Sağ ve sol elini çok iyi kullanabilmelidir.

- Ustanın en önemli özelliği yorum yapabilme derecesidir, iyi bir yorumcu olmalıdır.

- İcrasında her türlü teknik özelliklere (ajelite, pozisyon, glisando, çarpma vs.) sahip olabilmelidir.

- Özellikle Tanburi Cemil Bey, Refik Fersan, Şerif Muhittin Targan, Refik Tal'at Alpman, Münir Mazhar Kamsoy, Mesud Cemil Bey vb. bestekârların eserlerini, yukarıda sayılan özelliklere uygun bir şekilde icra edebilmek klasik kemençe ölçütlerini belirleyebilir.

Türk müziği çalgı eğitiminde her saza göre ayrı ayrı ölçütler belirlemek zor olacaktır. Klasik kemençe eğitiminde herkes tarafından kabul görmüş her seviyeye uygun sistemli metotlara sahip olunabilseydi, şu metodu şu seviyeye kadar gelen ya da bitiren evet usta icracıdır diyebilmemiz mümkün olabilirdi. Bu durumda usta icracılık konumuna sadece eserler üzerinden ölçütler belirlemek uygun olacaktır. Çalgının tınısal özelliklerini ortaya koyacak, sanatçının 
artistik kabiliyetini gösterebileceği teknik zorluklar içeren eserler seçmek, klasik kemençe usta icracılığında ölçütleri belirlemekte bizlere yardımcı olacaktır.

\subsection{Kemençe Usta İcracıları Kimlerdir? (Who are Master Performers at Kemancha?)}

Katılımcılara "Belirlediğiniz bu ölçütler doğrultusunda geçmişten bu yana kemençe sazında usta icracı olarak kimleri tanımlayabilirsiniz?" sorusu sorulmuş alınan dönütler sonucunda şu verilere ulaşılmıştır.

Görüşme formundan çıkan sonuçları göz önüne alarak, geçmişten bu yana kemençe sazında usta icracı olarak tanımlayabileceğimiz sazendelerin isimlerini herhangi bir ölçüye bağlı kalınmaksızın sıraladık.

Tanburi CEMIL BEY, İhsan ÖZGEN, Cüneyd ORHON, Hasan ESEN, Derya TÜRKAN, Vasilaki, Aleko BACANOS, Ruşen Ferit KAM, Kemal Niyazi SEYHUN, Ekrem ERDOĞRU, Nihat DOĞU, Neva ÖZGEN, Kaan SEZERLER, Filiz KAYA, Furkan BİLGI, Emre ERDAL, Hristos EKMEKÇİOĞLU, Sokratis SINAPOULOS.

\subsection{Kemençe Sazında Usta İcracılığa Yönelik Dağar Önerileri (Repertory Suggestions Concerning Virtuosity in Kemancha)}

Katılımcılara "Sizce Akademik usta icracılık kemençe eğitimi ve usta icracıların konser dağarları için önerilen ilk on eser neler olmalıdır?" sorusu sorulmuş alınan dönütler sonucunda şu verilere ulaşılmıştır.

Usta icracılık, usta icracılığın Türk müziğindeki yeri, usta icracı ölçütleri ve kemençe usta icracısının sahip olması gereken nitelikler sırası ile irdelenmeye çalışılmıştır.

Klasik Türk müziğini klasik Batı müziği ile karşılaştırdığımızda çalgıya özel eser dağarının yeterli boyutta olmadığı açıktır.

Bu sıkıntı kemençe dağarı içinde geçerlidir. Bugün sazında belli aşamalar kat etmiş usta icracılık derecesine erişmiş kişilerin çalabileceği kemençe sazına özel yazılmış eser dağarı ne yazık ki bulunmamaktadır. Bu sorundan yola çıkarak bu sazı icra eden kemençe sanatçılarının fikirleri doğrultusunda, kemençe sazında usta icracı diyebileceğimiz kişilerin konser programlarında çalabileceği ve bu sazın ileri icra eğitiminde kullanılabilecek eserler belirlenmeye çalışılmıştır. Görüşme formu sonucunda verilen cevaplar iki yönde şekillenmiştir;

A. Teknik bakımdan değeri yüksek ve ajeliteye dayalı eserler.

B. Klasik ekolde yer edinmiş makamların kullanıldığı, doğru perde kullanımı ve kişisel yoruma dayalı eserler.

A. Teknik bakımdan değeri yüksek ve ajeliteye dayalı eserler;

- Şedd-i Araban Saz Semaisi - Tanburi Cemil Bey

- Sultaniyegâh Sirto - Sadi Işılay

- Kürdilihicazkâr Saz Semaisi - Reşat Aysu

- Nihavend Saz Semaisi - Mes'ud Cemil Bey

- Karcığar Saz Semaisi - Reşat Aysu

- Nikriz Saz Semaisi

- Tahirbuselik Saz Semaisi

- Refik Fersan

- Suzidil Saz Semaisi

- Kemani Rıza Efendi

- Sedat Öztoprak

- Hüzzam Saz Semaisi

- Nevres Bey

- Arazbar Buselik Saz Semaisi

- Refik Fersan

- Acemkürdi Saz Semaisi

- Reşat Aysu

- Nihavend Saz Semaisi

- Kürdîlihicazkâr Longa

- Şerif Muhittin Targan

- Cinuçen Tanrıkorur 


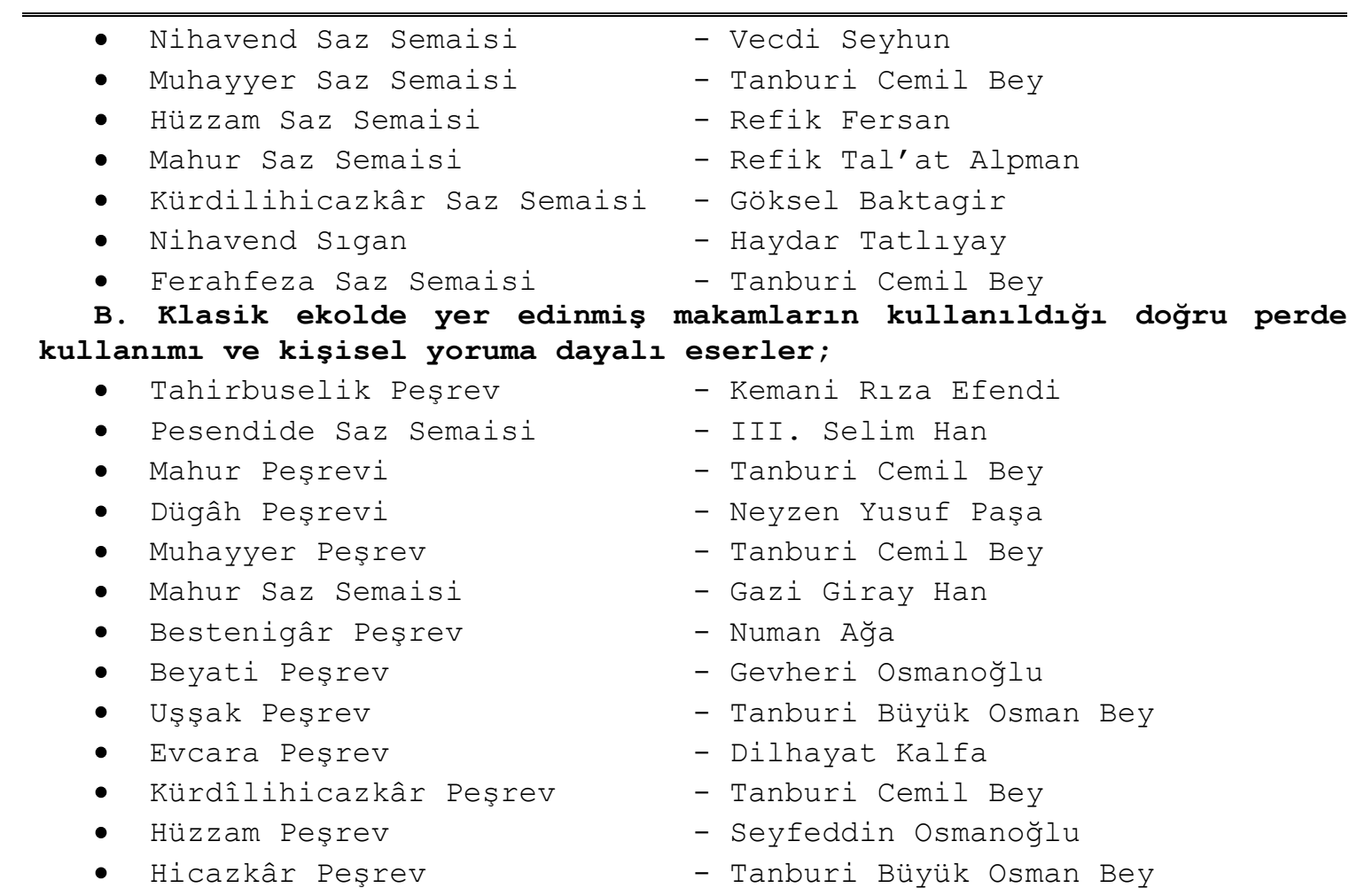

\section{SONUÇ VE ÖNERIILER (CONCLUSION AND RECOMMENDATIONS)}

Araştırma, usta icracı ve usta icracılık konumunu sorgulamak, usta icracılığa yönelik akademik eğitimin gerekliliğini ve önemini vurgulamak, dört telli kemençe eğitiminde usta icracılığa yönelik dağar önerileri sunmak için gerçekleştirilmiştir.

Kemençe eğitiminde usta icracılığa yönelik dağar önerileri sunabilmek ve alanında uzman kişilerin görüşlerini belirleyebilmek amacıyla sekiz sorudan oluşan yapılandırılmış görüşme formu hazırlanmıştır. İhtiyaç analizine yönelik verilerin çözümlenmesinde, sorulara verilen cevaplar, kullanma sıklığına göre benzer cümleler arasından seçilen ilgili örnek cümlelerle kategorilere ayrılarak maddeleştirilmiştir.

Bu araştırmada, usta icracılık, usta icracılığın Türk müziğindeki yeri, usta icracı ölçütleri ve kemençe usta icracısının sahip olması gereken niteliklere sırası ile değinilmiştir.

Klasik Türk müziğindeki usta icracılık ölçütlerinde sahip olunması gereken nitelikler belirlenirken Türk müziği, klasik Batı müziği ile karşılaştırılmıştır. Türk müziğinin söze dayalı bir müzik olması sebebi ile çalgıya özel eser dağarının yeterli boyutta olmadığı ve bu sebeple usta icracı ünvanının hakettiği yerde olmadığı konusuna dikkat çekilmeye çalışılmıştır.

Türk müziğindeki çalgıya özel dağar yetersizliği kemençe sazı içinde geçerlidir. Bugün sazında belli aşamalar kat etmiş usta icracılık derecesine erişmiş kişilerin çalabileceği kemençe sazına özel yazılmış eser dağarı bulunmamaktadır.

Araştırmada, bu sorundan yola çıkarak kemençe sazını icra eden sanatçıların fikirleri doğrultusunda, kemençe sazında usta icracı diyebileceğimiz kişilerin konser programlarında çalabileceği ve bu sazın ileri icra eğitiminde kullanılabilecek eserler belirlenmeye çalışılmıştır. 


\begin{abstract}
\begin{tabular}{ccccc}
\hline \hline Belirlenen & bu & eserler, kemençe & usta & icracılık eğitimi \\
programlarında & ve usta icraclların & konser & dağarı hazırlama
\end{tabular} aşamalarında kaynak oluşturabilecek niteliktedir. Öneriler;

- Türk müziğinde usta icracılığın önemi vurgulanmalıdır.

- Türk müziğinde çalgının solo ifadesinin önem taşıması için öncelikle çalgı müziği dağarı genişletilmelidir.

- Çalgıya özel eser besteleme konusu üzerinde durulmalıdır.

- Kompozisyon bölümlerinde saz müziği besteciliği konusunda teşvik edici çalışmalarda bulunulmalıdır.

- Eğitimciler usta icracılığa daha fazla değinmeli, usta icracılığa yönelik eğitim programları hazırlanmalıdır.

- Lisansüstü eğitimde usta icracılığa yönelik programlar açılmalı ve sanatçı ünvanına dikkat çekilmelidir.

- Bu sayede usta icracılık Türk müziğinde de ön plana çıkmalı ve çalgılarımız kendini uluslararası alanda gösterme fırsatını daha fazla yakalayabilmelidirler.

- Usta icracılığa yönelik akademik eğitimin biran önce ele alınması, çalgıya özel eser ve etüt dağarlarının hazırlanması ve eğitim programlarına alınması gereklidir.

- Türk müziğindeki her çalgı için usta icracılık eğitimine yönelik öğretim programları hazırlanmalı ve lisansüstü eğitimde uygulanmalıdır.

- Bu çalışma bu evrede kemençe sazı için hazırlanacak lisansüstü eğitim programlarına kaynak olabilecek niteliktedir.

\section{NOT (NOTICE)}

Bu makale, araştırmacı tarafından Afyon Kocatepe Üniversitesi Sosyal Bilimler Enstitüsü Müzik Anasanat Dalı'nda 2012 yılında tamamlanan "Dört Telli Klasik Kemençe Eğitiminde Usta İcracılığa Yönelik Dağar ve Çalma Önerileri" başlıklı sanatta yeterlik tezinden oluşturulmuştur.
\end{abstract}

\title{
KAYNAKLAR (REFERENCES)
}

1. Behar, C., (1992). Zaman, Mekân, Müzik Klasik Türk Musikisinde Eğitim (Meşk) İcra ve Aktarım. İstanbul: Afa Yayınları.

2. Bogdan, R. and Biklen, S.K., (1998). Qualitative Research for Education: An Introduction to Theory and Method. Boston, MA: Allyn \& Bacon.

3. Büyük Larousse Sözlük ve Ansiklopedisi.(1986). İstanbul : Milityet Gazetecilik A.Ş..

4. Demirbatır, R.E., (1998). Türkiye'deki Eğitim Fakülteleri Müzik Eğitimi Bölümlerinde Viyolonsel Eğitimi. Yayımlanmamış Doktora Tezi. Ankara: Gazi Üniversitesi Fen Bilimleri Enstitüsü.

5. Ekiz, D., (2003). Eğitimde Araştırma Yöntem ve Metotlarına Giriş: Nitel, Nicel ve Eleştirel Kuram Metodolojileri. Ankara: Anı Yayıncılık.

6. Gerçek, İ.H., (2008). Geleneksel Türk Sanat Müziğinde Meşk Sisteminden Notalı Eğitim Sistemine Geçişle İlgili Bazı Düşünceler. A. Ü. Türkiyat Araştırmaları Enstitüsü Dergisi: TAED, Sayı:38, ss:151-158.

7. Karasar, N., (1994). Bilimsel Araştırma Yöntemi: Kavramlar, İlkeler, Teknikler. Ankara: Araştırma Eğitim Danışmanlık Ltd.

8. Kaya, F., (2012). Dört Telli Klasik Kemençe Eğitiminde Usta İcracılığa Yönelik Dağar ve Çalma Önerileri. Yayımlanmamış 
Sanatta Yeterlik Tezi. Afyonkarahisar: Afyon Kocatepe Üniversitesi Sosyal Bilimler Enstitüsü.

9. Yıldırım, A. ve Şimşek, H., (2005). Sosyal Bilimlerde Nitel Araştırma Yöntemleri. Ankara: Seçkin Yayıncılık.

10. http://tr.wikipedia.org/wiki/Virtüöz (28.08.2012) 